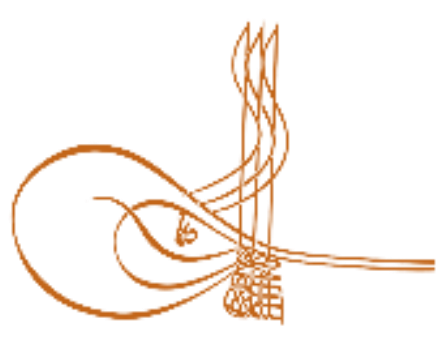

www.turkishstudies.net/social
Turkish Studies - Social Sciences

eISSN: $2667-5617$

Research Article / Araștırma Makalesi

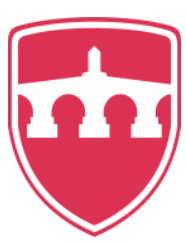

INTERNATIONAL

BALKAN

UNIVERSITY

Sponsored by IBU

\title{
Türk Yönetim Kültüründe Temel Etik Değerlerin İncelenmesi: Bir Siyasetname Örneği Olarak El Medinet'ül Fazıla"
}

\author{
Examination of Basic Ethical Values in Turkish Administrative Culture: "Al-Madinatul Fazila (The \\ Excellent City)" as an Example of Political Treatise
}

\author{
Vasfiye Çelik $^{* *}$ - Zeynep Duyar ${ }^{* * *}$
}

\begin{abstract}
When the Turkish administrative culture and the formation of the State tradition are examined, it is seen that ethical values as well as moral values are very important. When the administrative process is assessed in terms of moral and ethical values, the fact that the basic values such as justice, meritocracy, and goodness are considered as necessary conditions for good administration is informative about the State tradition. Because, ethics values and principles are emphasized also in the political treatises, which are accepted as one of the basic building blocks of administrative culture, these ethical values and principles are often mentioned as administrative principles, and the attention is drawn to the importance of these values in terms of the stability of administration/administrator and the survival of the state. Nowadays, although the ethical phenomenon is evaluated with new acceptable concepts such as accountability, transparency, openness, and professionalism as well as the principles stated in the political treatises, the origin is based on the old as seen in the example of political treatise. The content of Farabi's Al-Madinatul Fazila (The Excellent City), which is accepted as one of the first examples of political treatise, shows that the importance of ethical values and principles is emphasized in the discourses on how administration and administrator should be. In the study conducted theoretically in this framework, an evaluation of how the ethical values and principles, whose origins date back to very old times, and which gained clear statements in the early 2000s, were handled in Farabi's Al-Madinatul Fazila (The Excellent City), and Farabi's ethical understanding is tried to be put forward accordingly.
\end{abstract}

\footnotetext{
* Bu çalışma, 2019 yılında Kırıkkale Üniversitesi Sosyal Bilimler Enstitüsü’nde tamamlanan "Türk Yönetim Kültüründe Siyasetnamelerde Etik Değerler ve 2000 Yılı Sonrası Türk Kamu Yönetiminde Etik Anlayış Üzerine Karşılaştırmalı Bir Analiz" adlı yüksek lisans tezinden üretilmiştir.

** Dr. Öğr. Üyesi, Kırıkkale Üniversitesi, İ̈BF, Siyaset Bilimi ve Kamu Yönetimi Bölümü

Asst. Prof. Dr. Kirlkkale University, Faculty of Economics and Administrative Sciences, Department of Political Science and Public Administration

ORCID 0000-0002-2176-892X

vasfiyecelik@kku.edu.tr

*** Öğr. Gör., Kütahya Dumlupınar Üniversitesi, Gediz Meslek Yüksekokulu, Hukuk Bölümü

Lec. Kütahya Dumlupınar University, Vocational School, Law

ORCID 0000-0003-0408-4486

zeynep.duyar@dpu.edu.tr

Cite as/ Atıf: Çelik, V., Duyar, Z. (2020). Türk yönetim kültüründe temel etik değerlerin incelenmesi: bir siyasetname örneği olarak El Medinet'ül Fazıla, Turkish Studies - Social, 15(1), 187-206.
} https://dx.doi.org/10.29228/TurkishStudies.40227

Received/Geliş: 18 December/Aralık 2019

Accepted/Kabul: 25 February/Şubat 2020

Copyright $(\mathcal{C}$ INTAC LTD, Turkey

Checked by plagiarism software

Published/Yayın: 29 February/Şubat 2020

CC BY-NC 4.0 
Structured Abstract: Today, ethics is regarded as a guide to help individuals to find the right and the best in their attitudes and behaviors, as well as a part of public reforms and an indispensable element of the state in public administration. However, it was necessary to wait until the 1980s in order to take the concept of ethics into consideration and make it applicable in public administration systems, although this role has been attributed and it has a conceptually ancient history. Today's modern understanding of ethics acts as an expression of various ideologies, approaches, and opinions, with the idea of forming a citizen-oriented public administration structure that respects human rights as an equal, fair, democracy-based, and citizen-oriented structure. It is aimed to make public administration transparent and accountable by determining ethical codes and general principles that are valid especially for public administration, thereby achieving a more effective and efficient administration. At the same time, the idea that adhering to these principles will reduce and even prevent unethical activities in administration, thereby providing an environment in which the people receiving the service trust the state, institutions, and public officials.

When looking at the Turkish administration culture and the process of forming the state tradition, it is seen that ethical values are very important as well as moral values. When the administrative process is analyzed in terms of moral and ethical values, it is also informative about the state tradition to be regarded basic values such as justice, merit, and goodness among the necessary conditions of good management. Because, the political treatises accepted as one of the basic building blocks of the administration culture also focus on ethical values and principles, and these ethical values and principles are often mentioned as administration principles, and it is paid attention to the importance of these values in terms of the stability of the administration / administrator and the state's survival. Although the ethical phenomenon in the current century is evaluated with new concepts such as accountability, transparency, openness, and professionalism as well as the principles stated in the politics, its origin dates back to very old times as seen in the example of the political treatises. On the other hand, various dynamics stand out in terms of the Turkish administration culture, which is emphasized in the study, to have an evolving yet sustainable structure, but the main purpose is to have an ideal state order. In this framework, it is seen that some thinkers and statesmen have written the political treatises in order to indicate what are the necessary conditions for having an ideal state order and administration. These treatises have written to direct other officials under the governmental service, especially state administrators, to faithfulness and honesty; to instill the importance of public service thinking; to talk about the harms of negative behavior; and to advise an administration that exhibits fair, equal, and ethical behavior. These political treatises addressing the relations between the state and the public in many areas from ethics to politics, from economy to diplomacy, reflected the author's thoughts by including the religious principles and moral values as well as the concepts mentioned as administrative principles and containing ethical values and principles. In this study, it is aimed to show the evidence that some of the basic ethical values emphasized with the 2000s basically existed centuries ago through an exemplary political treatise.

It is seen that the importance of ethical values and principles is largely emphasized in the content of Farabi's "Al-Madina Al-Fadila" (the Virtuous State), which is accepted as one of the first examples of political treatises in the discourses about how administration and administrator should be. In this framework, the aim of this study conducted theoretically is to make an assessment of how the ethical values and principles, which gained clear expressions at the beginning of the 2000s but its origin is very old, were handled in Farabi's "Al-Madina Al-Fadila" (the Virtuous State), and to reveal Farabi's ethical understanding accordingly. As for the methodology, it is used the content analysis method. By this method, the content of Farabi's famous work "Al-Madina Al-Fadila" is examined objectively and systematically, and the existence of individual ethical values and principles are examined one by one.

In Farabi's work titled "Al-Madina Al-Fadila" (the Virtuous State), it was encountered with a small number of ethical values and principles determined in the 2000s. While today's ethical principles and values are longly listed as accountability, transparency, responsibility, justice, lawfulness, honesty and impartiality, equality, openness, leadership, merit and professionalism, objectivity, loyalty, courtesy and respect, respectability and trust, public service awareness, complying with service standards, adherence to the purpose and mission, notification to competent authorities, avoiding conflict of interest, prohibition of duties and powers to provide benefits, prohibition of receiving gifts and benefits, avoiding extravagance, and reporting goods, it is observed that Farabi's ethical understanding was formed by the influence of ancient Greek thinkers and Islam and it was constructed on the basis of happiness in essence. Because, in Farabi's teaching, one goal is to achieve happiness for the ruler of the Virtuous City and those under his administration. Although the concept of happiness is not seen as an ethical value in today's public administration systems, it

Turkish Studies - Social, 15(1) 
is also determined under the study that public officials exist in the point that they will be happy and satisfy the citizens who are waiting for service, if they act with the awareness of public service while performing their duties. In Al-Madina Al-Fadila (the Virtuous State), which was designed by Farabi and gives information about how to be the ideal state administration and administrator, a city image with all virtues has been drawn and explained in good and bad deeply, which is one of the first concepts to be used in explaining the concept of ethics. While the issues of "justice", "merit", "leadership", "being knowledgeable" that are among the ethical values and principles that have been in question since the 2000s are included throughout Al-Madina Al-Fadila (the Virtuous State), only these four principles stand out in the work when a comparison is made with today's ethical values. Of course, it should be noted that there are certain differences between the ethical understanding that Farabi has adopted and the modern ethical understanding of today, and the basis of this difference lies in the maturation of Farabi's ethical understanding on the grounds of religion-state-morality.

Another issue identified in this study is that the fact of ethics is still tried to be placed in today's administration process despite the fact that the administration culture has a deep and continuous structure, the principles of management were determined centuries ago, and some ethical values and principles were taken under the name of administration principles in the political treatises mentioned. As a matter of fact, the main purpose of the political treatises, which were started to be written since the 8th century in almost every period of the Turkish administration history, is related to the adoption of administration principles consisting of ethical values and principles in the state administration and the fight against corruption, in special to this political treatise. However, when compared with today, it is seen to go nowhere fast in terms of both individual and public officials in this issue. Although these negative developments are noticeable, the study is also planned to shed light on possible studies addressing the concept of ethics, which is still on the agenda as a new phenomenon.

Keywords: Ethics, Ethical Values, Political Treatise, Farabi, Al-Madinatul Fazila.

Öz: Türk yönetim kültürüne ve devlet geleneğinin oluşturulma sürecine bakıldığında ahlaki değerler yanında etik değerlerin de oldukça önemli olduğu görülmektedir. Yönetsel süreç, ahlaki ve etik değerler anlamında incelendiğinde ise adalet, liyakat, iyilik gibi temel değerlerin iyi yönetiminin gerekli şartları arasında sayılması devlet geleneği hakkında da bilgi verici nitelikte olmaktadır. Zira yönetim kültürünün temel yapı taşlarından birisi olarak kabul edilen siyasetnamelerde de etik değer ve ilkeler üzerinde durulmakta, bu etik değer ve ilkelerden çoğu zaman yönetim ilkeleri olarak bahsedilmekte ve yönetim/ yöneticinin istikrarı ve devletin bekası açısından bu değerlerin önemine dikkat çekilmektedir. Günümüzde her ne kadar etik olgusu, siyasetnamelerde belirtilen ilkeler yanında hesapverebilirlik, şeffaflık, açıklık, profesyonellik gibi yeni kabul edilebilecek kavramlarla değerlendirilse de siyasetnameler örneğinde görüldüğü üzere kökeni çok eski zamanlara dayanmaktadır. İlk siyasetname örneklerinden biri olarak kabul edilen Farabi'nin El Medinet'ül Fazıla (Erdemli Şehir) eserinin içeriğinde ise yönetim ve yöneticinin nasıl olması gerektiğine dair söylemlerde, etik değer ve ilkelerin önemi üzerinde fazlasıyla durulduğu görülmektedir. Bu çerçevede ve teorik olarak yürütülen bu çalışmada, kökeni çok eskiye dayanmakla birlikte net ifadelerini 2000'li yılların başında kazanan etik değer ve ilkelerin, Farabi'nin El Medinet'ül Fazıla (Erdemli Şehir) adlı eserinde nasıl ele alındığına dair bir değerlendirme yapılmakta ve bu doğrultuda Farabi'nin etik anlayışı ortaya konulmaya çalışılmaktadır.

Anahtar Kelimeler: Etik, Etik Değerler, Siyasetname, Farabi, El Medinet'ül Fazıla.

\section{Giriş}

1980'li yıllardan itibaren devletlerin ve dolayısıyla kamu yönetimi sistemlerinin ilgilendiği temel hususlardan birisi, sistemi şeffaf, hesap verebilir, etkin ve verimli bir yapıya kavuşturmak olmuştur. Bu durumun altında yatan temel nedenlerden biri ise etik dışı davranışların artması ile devlete ve devletin kurumlarına olan güvenin azalmasıdır. Bu olumsuzluğu ortadan kaldırmak adına da tüm dünyada hızlı ve aktif bir şekilde etik kavramının ne ifade ettiği, kamu etiği, etik norm ve standartlar, ilkeler ve kurallar belirlenmeye ve öğretiler geliştirilmeye başlanmıştır. 
Aslında etik kavramı her ne kadar yeni bir olgu olarak gündemde yer edinse de kökeni çok eskilere dayanmaktadır. Tarihteki pek çok filozofun etik anlayışı ve devlet adamlarının etik konusundaki görüş ve düşünceleri de bu durumu açıklar niteliktedir. Bu doğrultuda Türk yönetim geleneğinin dayandığg yönetim ilkeleri ve unsurları incelendiğinde ise adalet, liyakat, liderlik, doğruluk, iyilik gibi etik değer ve ilkelerin varlığı göze çarpmakta ve siyasetnamelerde bu değer ve ilkelere önemle vurgu yapıldığı görülmektedir. Bu süreç ve kavramsal yapıyı daha iyi analiz edebilmek amacıyla da Türk yönetim kültürü değerlendirildiğinde teşkilatlı bir yapıya sahip olunması, yöneten ile yönetilen sınıf arasında diğer toplumlarda olduğu çok sert bir sınırın olmaması, güçlü ve merkeziyetçi bir bürokratik yapı yanında uyulması gereken hukuk kuralları ve töre, lider vasıflı yöneticilerin yönetme sürecini adil bir şekilde yürütmesini sağlamıştır. Ancak zaman zaman bahsedilen bu yoldan sapmalar yaşanmış, bu olumsuzlukları düzeltmek adına da genelliklere hükümdara ithafen eserler yazılmıştır. Bu noktada ortaya çıkışı ve yazılışı yüzyıllar öncesine dayanan, iyi bir yönetim ve yöneticinin nasıl olacağına dair yöneticiye (hükümdara) tavsiyeler vermek için kaleme alınan, siyasetten felsefeye, edebiyattan tarihe kadar pek çok alanda önemli konumda bulunan siyasetnameler incelendiğinde en dikkat çekici olanlardan biri olarak 8 . yüzyılda Farabi tarafindan Türk-İslam senteziyle kaleme alınan El Medinetü'l Fazıla (Erdemli Şehir) isimli eser dikkat çekmektedir.

Din ve felsefeyi görüşlerinde bağdaştırmaya çalışan Farabi, kurgu eseri El Medinetü'l Fazıla (Erdemli Şehir) adlı eserinde "mutlulukçu" bir anlayış benimsemiştir. Her şeyin temeline bu kavramı koyan Farabi'ye göre bu kavramın dışında kalan iyilik, erdem, adalet, liyakat, liderlik gibi kavramlar mutluluğa göre şekil almakta ancak mutluluğu da iradi eylemlere dayandırarak insanların mutlu olmayı seçmede bilinçli davranışlarına dikkat çekmektedir. Bu çalışmada, bahsedilen bu anlayış doğrultusunda El Medinetü'l Fazıla (Erdemli Şehir)'da etik değer ve ilkelerin (adalet, iyilik, doğruluk, liyakat vb.) nasıl ele alındığı, eserin kaleme alındığı dönemde bireysel ve yönetsel etiğin ne anlama geldiği ve Farabi’nin genel etik anlayışı irdelenmeye çalışılacaktır.

\section{Etik Olgusu Hakkında}

Sosyal bir varlık olan birey, hayatı boyunca aldığı kararlarında ve davranışlarında, hem kendine hem de içinde bulunduğu topluma karşı sorumlu olmuş ve bu sorumluluk yükü ile hareket etmiştir. Bu açıdan bireyin nasıl davranacağına ve hangi değerler doğrultusunda kararlar alacağına ilişkin sorular, etik kavramını ve olası tartışmaları ortaya çıkarmıştır. Ancak bu tartışmalar sonucunda, sosyal bilimlerde tartışılan diğer kavramlarda olduğu gibi etik kavramı için de üzerinde anlaşılan tek bir tanıma ulaşılamamıştır.

Kökeni itibari ile etik kavramına bakıldığında Yunanca karakter veya davranış anlamında kullanılan "ethos" sözcügünden türetildiği, bu sözcükten türetilen "ethics" kavramının ise toplumda hâkim olan değerlerin, fikirlerin ve ideallerin bütünü şeklinde tanımlandığ1 görülmektedir. İdeal ve soyut olana işaret eden "ethics" kavramı, değerlerin ve ahlâk kurallarının incelenerek ilkeler halinde ortaya konulması sonucunda ortaya çıkmakla birlikte ahlak kurallarıyla karşılaştırıldığında daha özel ve felsefi olmaktadır (Fromm, 1994: XXXVII). Felsefenin bir dalı olarak etik ise değerlerin özü ve temelleri yanında insanın bireysel ve toplumsal yaşamındaki değer ilişkileri ile ilgili sorunları araştırmakta ayrıca tutumların, davranışların, düşüncelerin, inançların, eylemlerin vb. ahlaki vasıfların insani değerler açısından iyi, doğru ve kabul edilebilir olup olmadıklarına ilişkin çalışmaları içermektedir (Akarsu, 2010: 62; Yatkın, 2008: 213). Tek bir tanımı olmamakla birlikte "Etik, tarihte sıkışıp kalmış bir disiplin değil, insanlığın yaşayan, organik bir incelenmesi; doğruluk, iyilik ve adaletin gelişen bir muhakemesidir"(Yüksel, 2010: 28) ifadesi bu kavramın insanlık tarihiyle birlikte ortaya çıktığını ve temelde manevi değerlere vurgu yaptığını göstererek aynı zamanda neden tek bir tanımının yapılamadığını da ortaya koymaktadır.

Etiğin konusunun ne olduğu sorusuna verilecek ilk cevap ise yukarıdaki anlatımdan da anlaşılacağ üzere yalnızca son yıllarda gündemde olan kamu yönetimindeki yeni yaklaşımlarla sınırlandırılmaması gerektiği üzerinedir. Çünkü tarihsel süreç içinde düşünce, yönetim ve dinler 
tarihinde ortaya çıkan akımlar ve düşünürler incelendiğinde; Antik Yunan düşüncesinden Uzak Doğu yönetim felsefesine, Orta Doğu kökenli dinlerden aydınlanma çağına kadar etik olgusunun uygarlık tarihi boyunca işlendiği görülmektedir (Arap ve Yılmaz, 2006: 51). Bundan dolayı etiğin konusu, insanın eylemleri ve bu eylemlerle ilgili tüm faktörlerdir. Bu faktörler ise eylemin; gerçekleştirildiği koşullar, yöneldiği amaç, sonuçları, doğruluğu ve yanlışlığı, doğruluğunun temellendirilmesi gibi konuları kapsamakla birlikte hangi açıdan bakılırsa bakılsın amaç; akılcı mutluluğu aramak, mutlu yaşama sanatını yaratmak ve benimsemek olmuştur (Usta, 2010: 164165).

Tüm bu tanımlamalar doğrultusunda, temelinde insan ve insan davranışları olan etik kavramının insanlık tarihi boyunca devam eden ve edecek bir olgu olduğu söylenebilir. Hem bireysel ve toplumsal yaşamın en önemli parçası hem de yönetsel kültürün devamlılığını sağlayan en önemli öğelerden biri olarak etik, bireyin tüm hayatı boyunca içselleştirip benimsemesi ve hayatını buna göre idame ettirmesi gereken temel bir kavram olarak görülmektedir. Ayrıca devlet yapılarında da gerek kamuya istihdamda gerekse yönetsel siyasette uyulması gereken temel bir kavram olarak karşımıza çıkmaktadır.

\subsection{Yönetsel Etik}

Yönetim, insanlık tarihi kadar eski sosyal bir ihtiyaç olup insanların birbirleriyle ilişki kurmaları sonucu ortaya çıkmıştır. Çünkü birey, sosyal bir varlıktır ve de kendi başına bir hayat sürdüremeyeceğinden başka insanlarla mal, hizmet, yardımlaşma, bilgi ve benzeri konularda karşılıklı ilişkiler içinde olmak zorundadır (Eryılmaz, 2013: 1). Yönetim süreci ise sürekli olarak başkalarını yakından ilgilendiren ve etkileyen kararlar almayı; karar ve politikaları tüm toplumun yararına olacak şekilde uygulamayı; örgütsel ve bireysel ihtiyaçların karşılanmasını; çatışmaların örgüt ve bireylerin yararlarını gözetecek şekilde çözümlenmesini; örgütte yapılması gereken görevlerin, hakların ve sorumlulukların adil olarak paylaştırılmasını gerektirmektedir (Aydın, 2016: 53). Zaten kamu yönetimlerinin varlık nedeni de vatandaşlara eşit, adil bir şekilde kamu hizmeti sunarak onların ihtiyaçlarını gidermek, bu sayede toplumsal refahın artmasını sağlamaktır. Yönetsel etik olgusu da tam da bu noktada yani kamu hizmeti sunan kamu görevlilerinin keyfi bir şekilde hareket etmesini önlemek ve etik dışı davranışlarını engellemek için ortaya çıkmıştır.

Yönetsel etik, iyi ve kötüden oluşan bir kültür oluşumu (Saylam, 2007: 37) olarak bir yandan yöneticilerin ahlak dışı davranışlarda bulunmamaları için gereken şartlarla ilgilenirken diğer yandan yöneticilerin karşılaştıkları çıkar çatışmalarının ve ikilemlerin çözümünde onlara yardımcı olabilecek ilke ve standartların oluşturulmasını sağlamaya çalışmaktadır (Köprü, 2007: 20). Bu yönü ile yönetsel etik, örgütlerdeki bireylerin ahlaki karar almalarını ve bu durumu amaçlamalarını sağlamakta, doğru ve yanlışı ayırt etme yanında karar süreçlerinde doğru olanı tercih etmeye yönlendirme görevlerini üstlenmektedir (Saylı ve Kızıldağ, 2007: 233). Dolayısıyla yönetsel etik ile yönetsel kararların verilmesinde tutarlı, tarafsız ve gerçeklere dayalı olma; bireylerin varlık ve bütünlügüne sayg1; herkes için en iyi olacak eylemlerin seçilmesi ve eylemlerde adalet, eşitlik, tarafsızlık, dürüstlük, sorumluluk, saygı, açıklık gibi evrensel değerlerin temel alınması amaçlanmaktadır (Aydın, 2002: 41).

\subsection{Günümüz Yönetsel Etik Değerleri}

Etik değerler, amaca ulaşmak için kullanılacak araçlara ve alınacak kararlara yön verip kılavuzluk yapan, yol gösterici nitelikteki çerçeve kurallar olarak tanımlanmaktadır (Uluğ, 2009: 5). Söz konusu etik değerler ile varılmak veya elde edilmek istenen amaç ise devlette ve toplumda yolsuzluğu ve genel olarak yozlaşmayı önlemek ve dürüstlüğü hâkim kılmaktır (Şen, 2012: 11). Devlet görevlilerinin kendilerine verilen yetki ve kaynakları kullanırken halka hizmet bilinciyle hareket etmeleri, kamu menfaatini ön planda tutmaları ve tarafsızlık, dürüstlük, sadakat, saygınlık, güven, nezaket, saygı, liderlik, şeffaflık, hesap verebilirlik gibi etik davranış ilkelerine uymaları 
etkin, etik ve etkili bir yönetimin vazgeçilmez unsurlarından sayılmaktadır ki bahsedilen bu kavramların etikle ilişkisi anlamında biraz daha derinlemesine incelenmesi gerekmektedir.

İncelenmesi gereken kavramlardan ilki, kamu yönetiminde son zamanlarda çokça kullanılmaya başlayan ve kamu yönetiminin ve kamu yönetişiminin köşe taşı olarak değerlendirilen (Halachmi, Greiling, 2013: 566) hesap verebilirlik kavramı olup hükümetin uygulamalarının kontrol edildiği demokrasilerde, çeşitli kurumsal kontroller ve dengeler çeşidi olarak görülmektedir (Mulgan, 2000: 556). Kararlaştırılmış olan beklentiler çerçevesinde görev üstlenilmesi ve bu görevlerin sonuçları çerçevesinde başka bir otoriteye cevap verilmesi, açıklamada bulunulması ve rapor edilmesi (Karakaş, 2005: 292) olarak görülen bu kavram, yönetsel süreçte yol gösterme ve beklentileri açıklama, motivasyon, performansı izleme/ölçme gibi işlevleri de yerine getirmektedir (Acar, Guo, Yang, 2008:3). Geniş bir açıdan bakıldığında başarıyı ve hizmeti göstermenin bir fırsatı olarak kabul edilen, sonuç odaklı ve de şeffaf bir yönetim kültürünün yaratılmasında ve hükümet ile vatandaşlar arasındaki ilişkilerin güçlendirilmesinde olumlu bir itici güç olarak da değerlendirilen (Kesim, 2005: 270) hesap verebilirlik, devlet-vatandaş ilişkilerinde güvenin tesis edilmesini, bilgi alabilmeyi, kontrol etmeyi ve yön vermeyi içermektedir (Gül, 2008: 73-74). Sonuç olarak hesap verebilirlik ilkesi ile etik arasındaki yakın ilişki değerlendirildiğinde her ikisinin de bir kontrol biçimi olduğu ve kişiler ile kurumların sorumluluğunu geliştirmeyi amaç edindiği görülmektedir. Etik, kişinin içindeki akli ve vicdani kontrolü ve sorumluluğu kısacası inanç gücünü; hesap verebilirlik ise diştan kişiye yönelik bir denetim/kontrol sürecini anlatmaktadır (Eryılmaz, 2013: 407).

Hesap verebilirliğin yol arkadaşı olarak şeffaflık; devletin hedeflerini, bu hedeflere ulaşmak için ortaya koyduğu politikaları ve bu politikaların yarattığı sonuçları izlemek için gerekli olan bilgiyi düzenli, anlaşılabilir, tutarlı ve güvenilir bir biçimde sunmasıdır (Atiyas ve Sayın, 2000: 28). Şeffaflık ilkesinin en temel taşlarından birisi bilgi ve bilginin paylaşımıdır. Ancak bilgilerin paylaşılması yeterli olmamakta, ayrıca (Erdinç ve Gül, 2009: 957):

a) Kamu yönetiminde görevli kimselerin görevlerinin ve yetkilerinin açık olarak belirlenmesi,

b) Kamu yönetiminin tüm faaliyetlerinin, mevzuata ve gerekli koşullara uygun olarak bilgisinin tutulması ve saklanması,

c) Bu bilgilerin kamuya açık ve kolay ulaşılabilir olması,

d) Mali süreçlerin ve bütçeleme süreçlerinin açık olması,

e) Denetim mekanizmalarının varlığı ve işlerliği gerekmektedir.

Şeffaflık; yolsuzluğu önleyici en iyi araç, kamu çalışanlarının hesap verebilirliğini sağlayan bir ön hazırlıktır (Beth, 2005: 46) ve hesap verebilirlik ve kontrolle birlikte hizmet sunum sürecinde kullanıcıların ya da hizmetten faydalananların dürüst, etkin, doğru ve eşit muamele görmesine yardım etmektedir (Bertok, 2005: 87). Bu ilke, tüm yönetim ve kamu görevlileri tarafından uygulandığında etik dışı davranışları azaltan, yönetimi geliştiren, kamu görevlilerine ve devlete olan saygınlığı artıran ve de hesap verme sorumluluğunu teşvik eden önemli bir ilke olarak karşımıza çıkmaktadır. Ayrıca bu ilke ile kamu görevlileri, halkın bilgi edinme hakkını kullanmasina da yardımcı olmaktadır.

Şeffaf olmak aynı zamanda açıklık ilkesinin uygulanmasını gerektirirken bu ilkenin uygulanması sonucunda özel kişi, kurum, baskı grupları ve sivil toplum kuruluşlarının, yönetimin almış veya alacağı kararlara ve işlemlere katılma ve denetleme imkânı sağlanmış olacaktır (Yatkın, 2015: 155). Bir çeşit denetleme mekanizmasını da içinde barındıran bu kavram, yönetimin almış olduğu kararlardan doğrudan ve dolaylı etkilenecek olan gruplar tarafından özellikle kullanılmakta, bu da alınan karar ve uygulamaları etik ilkelere daha çok yaklaştırmaktadır.

Bahsedilen bu kavramların kullanılması ve karşılık bulması içinse hukuk kurallarının olmas1 gerekmektedir. Günümüz devletleri kendilerini hukuk devleti olarak tanımlarken kamu görevlileri de kamu görevini yerine getirirken yürürlükteki kanunlara, etik davranış kodlarına ve 
tüm yasal düzenlemelere uygun davranmal, karar verme aşamasında yasalara ve talimatlara uygun hareket etmeli, takdir yetkilerini anayasal amaçlara ve etik davranış kodlarının ruhuna uygun olarak kullanmalıdır (Yüksel, 2007: 584). Ancak kamu görevlilerine, görevlerini yaparken belli sınırlar dâhilinde esnek davranmaları için takdir yetkisi verilmiştir. Fakat bu durum "İdarenin belli konuda karar alıp almama veya birden fazla kararlar arasında seçim yapma imkânı" (Gözler ve Kaplan, 2014: 157) olarak tanımlanan takdir yetkisi kullanılırken hukuka uygunluğun aranmayacağı anlamına gelmemektedir. Zira hiçbir kamu görevlisi, takdir yetkisini keyfi bir biçimde kullanamaz ve buna imkân tanımaz (Öztürk, 2005: 342). Bu ilkeye aykırı davranılması hukukun üstünlügü anlayışına aykırı olacağından ve de yolsuzluğu, yozlaşmayı ortaya çıkaracağından kamu görevlileri kamu hizmeti görevini yerine getirirken tarafsız olmaya, eşit ve adil davranmaya dikkat etmelidir (Yatkın, 2015: 209). Hukuk devleti çerçevesinde, kamu görevlilerinin uyması gereken ilkelerden bir diğeri olan eşitlik ilkesi ise kanun önünde eşitlik ilkesinin bir uzantısıdır ve Anayasada "kanun önünde eşitlik" başl1klı onuncu madde de "herkes, dil, ırk, renk, cinsiyet, siyasi düşünce, felsefi inanç, din, mezhep ve benzeri sebeplerle ayrım gözetilmeksizin kanun önünde eşittir" şeklinde yer almaktadır (AY/md.10). Bu doğrultuda kamu görevlileri, kamu hizmetlerinden herkesin yararlanmasını sağlamalıdır. Kamu hizmetleri kişi, kurum vb. ayrım gözetmeksizin aynı durumda olanlara, aynı koşullara göre, aynı biçimde sunulmalı ve takdir hakkı kullanılırken dahi bu ilke gözetilmelidir. Zira kamu görevlilerinin, kamu hizmetlerinden yararlananları seçme ve ayrıcalıkta bulunma gibi bir hakları bulunmamaktadır.

Sorumluluk, manevi bir yükümlülük duygusudur ve kişinin manevi inanc1, etik değerleri ve meslek standartları bu duyguda insanlara rehberlik etmektedir. $\mathrm{Bu}$ nedenle etik değerler, sorumluluk duygusunun geliştirilmesinde ve kişinin kendi kendini yönetmesinde önemli bir yere sahiptir (Eryılmaz, 2013: 407). Etik tartışmaların merkezinde yer alan bir ilke olarak sorumluluk, ahlaki bir yaşamın bütün gereksinimlerini karşılayacak bir ifade olması yanında kişiye bireysel rollerinde ve toplumsal hayattaki konumunda bir takım yükümlülükler getirmektedir (Aydın, 2016: 69). Nitekim kamu görevlileri özellikle takdir yetkilerini kullanırken bu yetkiyi, görevlerine ve halka olan sorumluluk bilinçlerine göre yerine getirmelidir. İçsel değerlere devam eder nitelikte bir diğer kavram olarak dürüstlük, genel olarak doğruluk ve adalet kavramlarıyla ölçülmektedir (Koçberber, 2008: 71) ve kamu görevlileri; tüm eylem ve işlemlerinde yasallık, adalet, eşitlik ve dürüstlük ilkeleri doğrultusunda hareket etmek zorundadır (Şen, 2012: 38). Meslek etiği anlamında, sayılan bütün bu ilkeleri gerçekleştirecek nitelikteki çalışanlar ise liyakat ve profesyonellik ilkeleriyle seçilmeli ve bu ilke doğrultusunda hareket etmelidir. Liyakat ilkesi, 657 sayıll Devlet Memurları Kanunu temel ilkeler kısmında ve üçüncü maddede şu şekilde düzenlenmiştir (657 DMK/ md. 3): "Devlet kamu hizmetleri görevlerine girmeyi, sinuflar içinde ilerleme ve yükselmeyi, görevin sona erdirilmesini liyakat sistemine dayandırmak ve bu sistemin eşit imkânlarla uygulanmasında devlet memurlarını güvenliğe sahip kılmaktır."

Sayılan bu ilkeler hem insani değerler hem de kamu görevlilerinde bulunması gereken etik ilke ve değerler anlamında günümüzde sıkça dile getirilmektedir. Bu ilke ve değerler günümüz devletlerinde kültürel veya yönetsel farklılığa rağmen genel olarak kabul edilmekte, bu ilkelere uygun faaliyette bulunan kamu yönetimi sistemleri halkın gözünde meşru sayılmaktadır.

\section{Türk Yönetim Kültürü ve Unsurları}

Milletlerin ortaya çıkışında ve mevcudiyetlerinin devamında en önemli rol hiç şüphesiz kültür olgusuna aittir. Kültür, nesilden nesile aktarılarak gelişen maddi ve manevi bütün değerleri kapsamaktadır ve bu değer yargılarının içerisinde insanların davranışları, yaptıkları faaliyetler, kurdukları ilişkiler ve geliştirdikleri hemen hemen her şey yer almaktadır (Çeçen, 1985: 115).Yönetim süreci ve kültürü de devletlerin kuruluşundan itibaren ortaya çıkmakta ve Türk yönetim kültürünün oluşmasi; Türklerin bir boy halinde yaşarken devlet kurmasına, göçebe bir hayat sürerken yerleşik hayata geçmesine, diğer devletlerle ilişki kurmaya başlayarak yayılmasına kadar çok eski zamanlara götürülmektedir. Bu süreçte Türk kültüründeki en büyük değişme ve 
gelişmeler ise ilk olarak göçebe hayattan yerleşik hayata geçişle başlamıştır ve devlet/yönetim bilincinin oluşması da bu sürece denk gelmektedir. Türklerin yönetim yapısını değiştiren, etkileyen diğer önemli bir gelişme de İslam dininin benimsemesi olmuştur.

Asırlardır tarih sahnesinde var olan Türklerin zaman içinde yönetim yapısı ve şekli yanında sahip oldukları toprak bütünlükleri de değişmiş, ancak bu değişikliklere rağmen yönetici konumundaki kişinin uyması gereken kurallar ve sahip olması gereken özellikler neredeyse aynı kalmıştır. Hatta halkın onlardan beklentisi de yüzyıllar içinde pek değişmemiştir. Zira asırlar önce Türklerin tarih sahnesine çıkmasıyla belirlenen "yönetici adil, akıllı, bilgi sahibi, cömert, cesaretli, sağlam yapıl1, güler yüzlü ve yumuşak huylu olmalı, eșit hizmet sunmalı, aklı ve bilgeliği ile başarılı olmalı, hakka ve halka hizmet bilinci ile hareket etmeli" gibi unsurlar günümüzde de geçerliliğini korumaktadır (Baykara, 2011: 335).

$\mathrm{Bu}$ değerlendirmeler 1şı̆ğında Türk yönetim sistemi ve kültürünün oluşmasında çeşitli dinamiklerin etkili olduğu değerlendirmesi yapılmaktadır. Bu dinamiklerin başlıcaları toplumsal yap1 ve özellikler, ekonomik yap1 ve faaliyetler, güvenlik ihtiyacı ve askeri faaliyetler, siyasi özellikler ve inanç sistemi (Sığr1 vd., 2015: 22) olmakla birlikte Türk yönetim kültürünün belli başlı unsurları şöyle sıralanmaktadır;
a) Devlet geleneği ve teşkilatlı yapı
b) Yöneten- yönetilen sınıfin varlığı
c) Merkeziyetçi ve hiyerarşik yapı
d) Töre ve hukuk kuralları
e) Güçlü bürokratik yapı
f) Lider vasıflı yönetici anlayışı
g) Adil yönetim ve yönetici anlayış1

a) Devlet Geleneği ve Teşkilatlı Yapı: Türklerde milletin bekası devletle bir görüldüğünden tarih boyunca Türk devletlerinden biri yıkılırken diğeri onun yerini, boşluğunu doldurmuş ve bu vesileyle Türk kültürü ve yönetimi daima ayakta tutulmuştur.

Bu çerçevede uzun ömürlü devletlere bakıldığında teşkilatlı ve sağlam temellere dayandığı görülmektedir. Nitekim tarih boyunca kurulmuş Türk devletlerinin her birinin bir imparatorluk haline gelmesi, Türklerin teşkilatçı bir karaktere sahip olmasından ve devletin idari, sosyal ve iktisadi yapısının her kesimden halkla bütünleşmesinden kaynaklanmaktadır. Ayrıca bu gelenek ve teşkilatlı yapı sayesinde medeni düşünce en olgun seviyeye ulaşmış; devlet yapısı içerisinde insani değerlere önem verilmiş, kişi inanç, hak ve hukukuna sayg1 gösterilmiştir (Halaçoğlu, 2014: XIII).

b) Yöneten- Yönetilen Sınıfın Varlığı: Türk yönetim kültürünün unsurlarından birisi de yöneten-yönetilen sınıfın mevcut olmasıdır. Ancak bu sınıf, hiçbir zaman kast sistemine benzer bir yapı olmamıştır ve yönetim, bir sosyal paylaşım fonksiyonu olarak tanımlanmıştır. Yönetenyönetilen ayrımı ise "On cengaverin içinden hükümet ve dirayeti nefsinde cem edeni diğer dokuzun rızası ile onların başına onbaşı yapılsın" anlayışıyla yapılmıştır ve ne olursa olsun yönetici vasfina sahip kimselerin ve diğer devlet görevlilerinin hangi seviyede olduğuna bakılmaksızın, halkın onayını almaları şart koşulmuştur (Sı̆grı vd., 2015: 24).

Yöneten değerlendirmesinde bazı milletlerin kültüründe "kral hata yapmaz ve her zaman masumdur" inanışının Türk yönetim anlayışındaki karşılığı farklıdır. Şöyle ki hükümdar; adil, bilge ve iyi olduğunda Tanrı'nın onunla olduğuna eğer adaletsiz, cahil ve zalim ise Tanrı'nın ondan uzaklaştığına inanılmıştır (Kılıç Özkaynar, 2017: 18). Türk yönetim kültürünün oluşması ve sürdürülmesinde yönetilen ve yöneten sınıf arasındaki ilişkiler önemli bir yer tutmakla birlikte sürekli etkileşim içinde yönetilenlerin istek ve şikâyetlerinin yöneticilere iletildiği, sorunlara yönelik çözümler üretildiği ve hesap verebilirliği artıran mekanizmalara İslamiyet Öncesi Türk Devletlerinden günümüze kadar her daim ancak farklı adlarla yer verilmiştir (Alodalı ve Usta, 2017: 169). 
c) Merkeziyetçi ve Hiyerarşik Yapı: Türk yönetim kültürünün unsurlarından bir diğeri ise merkeziyetçi ve hiyerarşik yapıdır. İlk Türk devletlerinin kurulmasından günümüze kadar güçlü bir merkeziyetçi yapı ve bu merkeziyetçi yapının içerisinde hiyerarşik bir yapılanma mevcut olmuştur. Devlet merkezden tek bir kişinin otoritesi altında bir bütünlük içinde yönetilmiştir. Bu sayede devlet sınırları içinde ayrım gözetmeksizin adil bir yönetim gerçekleştirilmiş ve eşit hizmet sunulmuştur.

d) Töre ve Yazılı Hukuk Kuralları: Bazı toplumsal norm ve kurallar zaman içinde Türklerin hukuk anlayışının oluşmasında etkili olurken ilk dönemlerde yazılı olmayan hukuk kuralı olarak benimsenen töre, bu açıdan büyük önem arz etmektedir (Mandaloğlu, 2013: 135). Töre, İslamiyet'ten önceki Türk toplumlarının temel değeri olmuștur ve Türk yönetim anlayıșında töreye verilen değer "il (devlet) gider, törü (töre) kalır" sözü ile ifade edilmiştir (Koca, 2002: 15). Nitekim bu sözle devletin varlığı ve siyasi hâkimiyetin devamının töre sayesinde olduğu, törenin uygulanmadığı yerde siyasi hâkimiyetin elden gideceği ve devletin son bulacağı vurgusu yapilmaktadır.

Töre, eski Türk yönetim anlayışında hem idare ve siyaset açısından olmazsa olmaz bir unsur, hem de eski Türk ahlakında yer alan cesaret, kötülükten korunma, başkalarını aldatmama, vefakârlı bir hayat düzeni sağlayan "utanma" duygusu gibi faziletlerin benimsenmesini sağlayan temel öğe olmuştur (Kafesoğlu, 1995: 334). Önemini açılamak anlamında töreye göre hükümdar, ülkenin sahibidir ve bundan dolayı tebaasının canı ve malı üzerinde tasarruf yapma hakkına sahiptir. Ancak bu durum keyfi olarak değil, kanun, nizam ve diğer uygulamaların gereklerine göre yürütülmüştür. Tarihsel olarak bakıldığında ise töre, devlet yönetiminde tek dayanak olmamıș İslamiyet'in kabulünden sonra şeriat kuralları da sisteme dahil edilmiştir. Türk İslam devletlerinde ve Osmanlı Devleti'nde kanun ve nizamlar İslam hukukuna dayanmış, gerekli kurallar Kur'an, hadis, icma ve kıyas gibi İslam'ın temel ilkelerine göre belirlenmiştir. Öte yandan şer'i hukuka aykırı olmamak kaydıyla hükümdarın toplum yararına vereceği hükümler, örf adı altında toplanmış ve hükümdarın yasama yetkisini genişletmiştir (Halaçoğlu, 2014: 2).

Töreye atfedilen değer öylesine büyük olmuştur ki etkin hukuk kurallarının konulması ve bunlara eşitlik ve adalet ilkeleri çerçevesinde riayet edilmesi, hem hükümdarın iktidarı hem de devletin sürekliliği için en önemli koşullar arasında sayılmıştır. Bundan dolayı, kaynaklarda törenin önemi vurgulanırken devletten bile önemli olduğu, töresini kaybetmiş bir milletin yok olmuş sayılacağı hatırlatılarak, hükümdarlardan her ne koşulda olursa olsun töreye uygun davranmaları beklenmiştir. Hükümdarlar da töreye uygun davranmayı kendilerine önemli bir görev sayıp her zaman halka karşı kendilerini sorumlu hissetmişler ve yaptıkları hemen her şey ile ilgili olarak topluma adeta hesap verici açıklamalarda bulunmuşlardır (Pamir, 2009: 360).

e) Güçlü Bürokratik Yapı: Türkler, devlet teşkilatlarını kurarken bürokrasi de kendine has özellikleriyle oluşmuş ve olgunlaşmıştır. Türklerde devlet kadroları uzman kişilerden oluşup, yönetimde kararlılık ve uzun memuriyet düşüncesi esas alınmıştır. Dahası tarihin her döneminde, Türklerin örgütlenerek varlıklarını bugünlere kadar getirmelerindeki en büyük etken, karakterlerine uygun bir yönetim tarzı oluşturmaları ve bunu sürekli geliştirerek uygulamaları olmuştur. Kurdukları güçlü bürokratik yapı sayesinde de dünyaya nizam verme gibi büyük bir iddianın da sahibi olmuşlardır (Terzi, 2015: 301).

f) Lider Vasıflı Yönetici Anlayışı: Bütün toplumlarda; toplumu yönetecek, talep ve ihtiyaçların karşılanmasında insanlara yardımcı olacak, zamana ve şartlara uygun stratejiler uygulayacak bir lidere ihtiyaç duyulmuştur (Kılıç Özkaynar, 2017: 12). Türklerde bu anlayış değerlendirildiğinde hâkim olan temel prensip, devlet içinde tek bir otoritenin bulunması yani otoritenin bir kişi de toplanması olmuştur ve bu kişi, yönetim becerilerini sergilediği dönem boyunca kutsal sayılmıştır (Sığrı vd., 2015: 16). Tarihe bakıldığında başarıları ile adlarından söz ettiren, üstün zekalı, cesaretli, adil, ileri görüşlü birçok Türk lider bulunmaktadır ki bu büyük liderler bir çağın kapanmasına yeni bir çağın açılmasına sebep oldukları gibi dünyadaki dengelerin

www.turkishstudies.net/social 
yeniden tanzim edilmesini de sağlamışlardır (Kılıç Özkaynar, 2017: 12). İlk teşkilatlanmayı sağlayan Metehan, Büyük Selçuklu hükümdarı Alparslan, bir boy iken cihana hâkim olan bir devlet kuran Osman Bey, bir çağ kapatıp bir çağ açan Fatih Sultan Mehmet ve yıkılmak üzere olan bir imparatorluktan güçlü bir devlet kuran Gazi Mustafa Kemal Atatürk, Türk yönetim ve siyaset geleneğinde lider vasıflı yönetici anlayışını en iyi yansıtan örneklerdir.

g) Adil Yönetim ve Yönetici Anlayışı: Türk yönetim kültürünün yapı taşı ve en önemli unsurlarından birisi de adil yönetim ve yönetici anlayışıdır ve Türkler, devlet yönetiminin birinci şartı olarak halka karşı adil olma erdemini tarihin ilk dönemlerinden itibaren benimsemiştir (Taneri, 1981: 217). Nitekim gerek töresi, gerek teşkilatlı yapısıyla kendine has bir yönetim modeli olan Türk yönetim sistemi, adalet ilkesi üzerine kurulmuş, adaletin esasını da kanunlar oluşturmuştur (Terzi, 2015: 25).

\section{Türk Yönetim Kültüründe Siyasetnamelerin Yeri ve Önemi}

Türk yönetim kültüründe yeri ve önemi oldukça büyük olan siyasetnamelerde işlenen düşünceler, Türk devlet teşkilatının ve yönetim sürecinin genel yapısı hakkında bilgi verirken, ahlaki temelini de oluşturmaktadır. Geçmiş ile bugünü birbirine bağlayan köprü niteliğindeki bu eserler, bugün bile süregelen yönetsel sorunları işlemeleri ve bu sorunlara çözümler sunmaları bakımından da ayrıca önem arz etmektedir.

\subsection{Siyasetnamelerin Tanımı}

Köken itibariyle Arapça siyaset (insan topluluklarını yönetme, devlet işlerini yürütme sanat1, politika) ve Farsça name (mektup, yaz1) kelimesinden meydana gelen Siyaset-name, "devlet adamlarına siyaset sanatı hakkında bilgi vermek, devlet yönetiminde dikkat edilmesi gereken hususlara dair tavsiyelerde bulunmak amacıyla yazılmış kitap veya bu kitapların oluşturduğu bir tür" anlamında kullanılmaktadır (Adalıŏglu, 2009: 304). Türk Dil Kurumu Güncel Türkçe sözlüğünde ise siyasetname "siyaset bilimini anlatan ve bu konuda öğ̈̈t veren eser" olarak tanımlanmaktadır (tdk.gov.tr, 2019).

Devlet teşkilatı ve yönetimi hakkında bilgi vermenin ve yönetimde meydana gelen sorunlara karşı nasihatler sunmanın yanında yöneticilerin adaletli bir yönetim oluşturmalarını sağlamak amaciyla yazılan siyasi ve ahlaki içerikli eserler ( Belen, 2015: 276) olan siyasetnameler, genellikle devlet yönetiminde tüm gücü elinde bulunduran hükümdarlara ithafen yazılmıştır. Bu eserlerde hükümdarın sahip olması gereken özellikler yanında yönetimin esas ve şartları tek tek sıralanmış, ideal bir devlet yönetiminin nasıl olması gerektiğine ve buna nasıl ulaşılacağına dair nasihatler verilmiştir. Aynı zamanda hükümdara halkın durumu ve toplumun genel hali anlatılıp kötü yönetimin zararları da açıklanmıştır. Hükümdarın isteği doğrultusunda ve hükümdarlar adına yazılan siyasetnameler dışında vezirler ve emirler için yazılmış siyasetnameler de vardır. $\mathrm{Bu}$ siyasetnamelerde vezirliğin şartları ve yetkilerinin neler olduğu üzerinde durularak; vezirlerin görevleri, hükümdarlara karşı tutumları, halkla olan ilişkilerinden bahsedilerek çeşitli öğütler verilmiş, ayrıca devlet yönetiminin şerefli fakat güç bir sanat olduğu da sürekli vurgulanmıştır (Levend, 1962: 168).

Levend (1962: 169-170) siyasetnamelerin içeriklerini genel itibariyle incelemiş ve belli başlı hususlar üzerinden yazıldığına dikkat çekmiştir. Bu hususlar: "1)Saltanatın temeli adalettir. Şecaat ve cömertlik de saltanatı kuvvetlendiren iki dayanaktır. 2) Hükümdar bu nimetin şükrünü, "tebaa" ve "reaya"ya karşı göstereceği adaletle ödemelidir. 3) Hükümdarlık şartları, hükümdara yakışacak huylar. 4) Hükümdarda bulunması gereken başlıca faydalı davranışlar ve erdemler ( adalet, cömertlik, şecaat vb.) 5) Dinin ve ahlakın emrettiği maddeler (rahmet, şefkat, hakkı yerine getirmek, çabuk öfkelenememek vb.) 6) Kaçınılması gereken haller (zulüm, hasislik, kibir, gurur vb.) 7) Danışmanın faydaları. 7) Hükümdarın nedimleri, musahipleri ve yakınları. 8) Devlet işlerinin ehil adamlara verilmesi. 9) Derecelerinin gözetilmesi. 10) Maliye ve hazine hakkında ögütler. 11) Tebaa ve reayanın hali. 12) Tımar ve zeamet erbabının durumu. 13) Hükümdarın 
vezirlere, kadılara, bilginlere karşı tutumu. 14) Hükümdarın halkla münasebeti, halkın şikâyetini dinlemesi. 15) Hükümdarın askerlere karşı davranışı; ulufenin zamanında verilmesi. 16) Işs başındakilerin halka zulmü. 17) Memurların görev ve şartları. 18) Şeriatın gerektirdiği cezalar. 19) Başka memleketlerle olan münasebetler. 20) Düşmana yapllacak işlem. 21) Cenk, yasa ve töreye uyma. 22) Yönetim işleri. 23) Sarayın durumu. 24) Hizmet sahipleri. 25) Memleket yönetiminin dayandı̆̆ esaslar. 26) Bir devletin çökmesinin nedenleri."

Siyasetnameler, Türk yönetim düşüncesi ve siyasal hayatı açısından olduğu kadar ekonomik ve sosyal yapı, hukuk, tarih araştırmaları açısından da birinci derecede kaynak özelliğine sahiptir (Yılmaz, 2009: 307). Yazıldıkları alan itibariyle önem arz eden bu eserleri yazan kişiler incelendiğinde ise iyi bir eğitim görmenin yanı sıra, devlet tecrübesine de sahip oldukları görülmektedir (Memiş, 2015: 103).

\subsection{Siyasetnamelerin Ortaya Çıkışı}

Birçoğu günümüze ulaşan ve devlet adamları tarafından kaleme alınan siyasetname ve bu türdeki eserler, içinde bulunulan dönemin koşullarına uygun olarak yazılmıştır ve siyasi öğüt niteliği taşımaktadırlar. İçerikleri itibariyle ahlak, siyaset, ekonomi, diplomasi gibi temel konuları kapsayan bu eserler, siyaset felsefesi ve kamu yönetimi açısından incelendiğinde yazıldıkları dönem ile içinde bulunulan coğrafyadaki siyasi hâkimiyet ve devlet yönetimini de açıkça ortaya koymaktadır (Evkuran, 2009: 642).

Genel itibariyle, siyasetnamelerde ideal bir devlet yönetimi için olması ve yapılması gerekenler açık ve geniş bir şekilde anlatılmaktadır. Olması gereken bu yönetim sistemi de devletin, yöneticinin, halkın en iyi durumda olduğu "tarihteki altın çağ" olarak adlandırılmaktadır (Çiçek, 1997:1385). Her ne kadar siyasi, ilmi ve fikri anlamda en iyi durumda bulunulan durumlarda kaleme alınan siyasetnameler olsa da "hükümdar aynaları" olarak da isimlendirilen bu eserlerin (Önder, 2018: 12) birçoğu için "tarihteki altın çağ" esasen hiçbir zaman söz konusu olmamıştır ve devletin bunalım dönemlerinde bir bozulma/yozlaşma yaşayan devlet adamlarını dürüstlüğe ve ahlaki/etik ilkelere uymaya yönlendirmek ve onlara ideal devlet yönetiminin ve yöneticisinin nasıl olması gerektiğini anlatmak için kaleme alınmıştır (Çiçek, 1997: 1385).

Türk yönetim sistemi dahilinde devletin ve bürokratik yapının gelişmesi, devlet yönetimi ve toplumsal yapıda meydana gelen birtakım sorunlar, yeni düşünce akımlarının ortaya çıkması, yönetsel ve siyasal alandaki değişme, gerileme ve gelişmeler zaman içinde siyasetname türündeki eserlerin artışına neden olmuştur (Yılmaz, 2009: 307).

\subsection{Siyasetnamelerdeki Etik ve Ahlak Anlayışı}

Siyasetnamelerin, genel olarak ahlaki eserler sınıfında yer aldığı kabul edilmektedir. Zira siyasetnamelerde, işlenen konuların hemen hemen hepsi dini esaslara dayandırılmış (Levend, 1962: 171), olması gereken yönetim sisteminin işleyişi şahıslardan bağımsız olarak liyakate ve nizama bağlanmış, devlet yöneticisine geniş kapsamlı görev ve sorumluluklar verilmiştir (Yılmaz, 2009: 308).

Devlet yöneticilerine, devlet yönetimi ile alakalı bir nevi danışmanlık hizmeti sunan siyasetnamelerde (Önder, 2018: 16) genel olarak yetenekli, dürüst, çalışkan ve fedakâr kimselere devlet işlerinin gördürülmesi gerekliliği vurgulanmakta, devlet yönetiminin kutsal, şerefli bir görev olmasının yanında zor bir zanaat olduğu da dile getirilmektedir. Nitekim en bilinen siyasetname örnekleri olan Nizamülmülk Siyasetnamesi, Kutadgu Bilig, Erdemli Şehir, Koçi Bey Risalesi yüzyıllar boyunca Türk hükümdarlarının ve devlet adamlarının toplumu ve devleti yönetebilmek için önemle okuyup, içeriğinde belirtilen esaslara göre hareket ettikleri eserler olmuştur (Memiş, 2015: 102).

Tüm siyasetnameler, halk ile siyasi aktörler arasındaki ilişkilerin nasıl olması gerektiğini açıklamaya çalışmakta, devlet ile halk arasındaki kopukluğun siyasi hâkimiyet unsurlarının 
sorgulanmasına sebep olacağına işaret etmektedir. Çünkü siyasetname geleneğine göre devlet, hükümdarın kuvvet ve kudreti yani otoritesinden başka bir şey değildir. Siyaset ise, hükümdarın otoritesini koruma ve kuvvetlendirme ve bunun vasıtalarını, yani asker ve para sağlamayı halkın hoşnutsuzluğuna sebep olmadan sağlama yoludur. Halkın huzursuzluğu ve hoşnutsuzluğu ise otoriteyi tehlikeye düşüren, fakirliğe yol açan bir durumdur. Kutadgu Bilig'in yazıldığı dönemden itibaren hükümdara bundan şiddetle kaçınması gerektiğine dair tavsiyeler verilmiştir. Bunun yolu da ancak adil olmakla mümkündür, çünkü hâkimiyet adalete sıkı sıkıya bağlıdır (Çiçek, 1997: 1385).

Türk yönetim kültüründe yer alan siyasetnamelerde iyilik, görev ve sorumluluk, liyakat, adalet, doğruluk, dürüstlük, eşitlik, halka hizmet bilinci, sadakat, güven gibi etik değer ve ilkelere yer verilmekle birlikte, bu değerlerin yaygınlaştırılması devletin temel fonksiyonu olarak belirlenmiştir. Ayrıca toplumu güçlü kılan ve devlet yönetiminin icrası için gerekli olan faziletlere, ahlaki özelliklere de siyasetnamelerin içeriklerinde sık sık yer verilmiştir.

\section{Farabi ve El Medinet'ül Fazla (Erdemli Şehir)}

Muhammed bin Tarhan Bin Uzluğ El- Farabi (d. 870(?) Farab, Maveraünnehir- ö. Aralık 950, Şam) Ortaçağın en büyük İslam düşünürlerinden birisi olup, Orta Çağ Latin dünyasında Alpharabius ya da Avennasar olarak tanınmış ve Aristoteles'in felsefesini yeniden yorumlayarak İslam düşüncesiyle bağdaştırmaya çalışmıştır. Bu sayede İslam'ın Altın Çağının en önemli isimlerinden olan Farabi, "ilk öğretmen" sayılan Aristoteles’ten sonra "ikinci öğretmen" olarak anılmaktadır (Ana Britannica, 1994: 77). Başta Aristoteles olmak üzere eserlerini ve düşüncelerini incelediği Yunan filozoflarının asla bir taklitçisi olmayan Farabi, görüşlerinde din ve felsefeyi bağdaştırmaya çalışmış ve geniş ölçüde İslami ilimlere ağırlık vermiştir (Çubukçu, 1989: 16).

Farabi'nin başyapıtı sayılacak Erdemli Şehir adlı eseri ise Türk-İslam düşünce hayatında hiç kuşkusuz oldukça önemli bir yer tutmaktadır. Farabi'nin felsefi görüşleriyle kurguladığı toplum-devlet ilişkisini son derece açık bir biçimde anlatması eserin önemini arttıran başlıca unsur iken Eski Yunan Felsefesi ile İslam Felsefesi arasındaki karşılıklı etkileşimi ortaya koyması eseri önemli kılan bir başka neden olarak karşımıza çıkmaktadır (Demirel, 2014: 359). Dahası Erdemli Şehir, Farabi'nin etik ve ahlak anlayışını yansıttığı eseri olarak da dikkat çekmektedir.

\subsection{Farabi'nin Etik Anlayıșı ve El Medinetü'l Fazıla(Erdemli Şehir)'da Etik Değerler}

Farabi'nin, etik anlayışı Yunan düşünürlerinden olan Sokrates'in etik anlayışına benzemektedir. Çünkü Farabi de Sokrates gibi "mutlulukçu” bir etik anlayış benimsemiştir (Özlem, 2010: 49-50). Bu bağlamda Farabi'ye göre insanın nihai amacı mutluluk ve erdeme ulaşmak olup, Farabi bunu amaçlayan yönetime "El-Medinet'ül Fazıla (Erdemli Şehir)", şehir yöneticisine de Erdemli Başkan adını vermiştir.

\subsubsection{Mutluluk}

Farabi'ye göre "mutluluk" salt idea, aynı zamanda salt iyiliktir. Bu mutluluğun başarılması ve elde edilmesi için yararlı olan her şey iyidir; ancak bu iyilik, onların özünde olmayıp mutluluk için yararlı olmalarındandır. Mutluluğun elde edilmesinde yararlı olan iyilik ya tabii olarak vardır ya da irade ile ortaya çıkmaktadır. Herhangi bir mutluluğa giden yolu tıkayan her şey ise salt kötülüktür. Mutluluğun yolunu engelleyen kötülük de ya tabii olarak vardır ya da irade ile ortaya çıkmaktadır (Farabi, 2017a: 84-85). Bütün yapılanlar nihai olarak en mükemmel olana ulaşmak içindir, o da mutluluktur. Mutluluk, insan ruhunun varlık bakımından güç alacağ maddeye ihtiyaç duymadığı bir mükemmellik derecesine ulaşmasıdır (Farabi, 2017b: 83-84).

Dahası mutluluk, kendisi için istenen, hiçbir zaman bir başka şeyin elde edilmesi için istenmeyen "iyi" dir. Onun ötesinde insanın elde edebileceği daha büyük bir şey yoktur (Farabi, 2017b: 84). Çünkü Farabi’ye göre, mutluluğun elde edilmesi insanın yaratılış sebebini oluşturur.

Turkish Studies - Social, 15(1) 
$\mathrm{Bu}$ nedenle erdem, iyilik gibi kavramlar mutlulukla kıyaslanınca ikinci derecede önem arz etmektedir (Farabi, 2017a: 14).

\subsection{2. İyilik ve Erdem}

Mutluluğun elde edilmesi için yararlı olan iradi eylemler, güzel eylemlerdir. Bu eylemlerin ortaya çıktığı yetenekler ise erdemlerdir. Bunlar kendi özleri bakımından değil mutluluğun kendisinden ötürü iyi şeylerdir. Mutluluğa engel olan eylemler ise kötü huylardır ve bunlar eksiklikler, erdemsizlik ve aşağılık olarak nitelendirilir (Farabi, 2017b: 84).

Farabi’ye göre iradi (istenerek yapılan) iyilik ve kötülükler, yani güzel-çirkin, doğru-yanlış bütün şeyler insanların davranışlarından kaynaklanır( Farabi, 2017a: 86). İnsan mutluluğu; en üstün, bütün yaratılanların üzerinde, daima bilen, etkin olan (Stroll vd., 2017: 79) ve ideal devlet yöneticisi olmanın meşru ölçütü sayılan, peygamberlerin ve filozofların bu akılla bir bağ kurmaları sayesinde ideal devlet yönetici olabilecekleri vurgulanan "Faal akıl" (Ayaz, 2008: 39) tarafindan kendisine verilmiş olan ilkeleri ve ilk bilgileri kullanmakla bulmaktadır. O, mutluluğu bilir ve onu elde etmek için doğru eylemlere ve davranışlara yönelir, böylece insandan meydana gelen her şey bütünüyle iyi olur. Bu sayede iradi iyilik ortaya çıkar. İradi kötülük ise insanın mutluluğun bilincinde olup ona doğru yönelmemesi; yarar, zevk, egemenlik, şeref gibi gerçek mutluluğun dışındaki bir şeyi hayatında amaç edinmesi ve onun için çaba harcaması ile ortaya çıkmaktadır (Farabi, 2017a: 86-87). Farabi bu durumu daha açı bir şekilde şöyle ifade eder: "Gerçek mutluluğun kendisiyle elde edildiği şeyler iyi, asil ve erdemli şeylerdir; gerisi, kötü, bayağı ve erdemsiz şeylerdir" (Stroll vd., 2017: 79).

$\mathrm{Bu}$ noktada Farabi, insanların erdemleri öğrenebilmeleri ve doğru eylemler göstermeleri konusunda onları yöneten devlet başkanının niteliklerinin ve rolünün önemli olduğunu zikreder. Devlet başkanının erdemli olması yönettiği şehir halkının da erdemli olmasını sağlarken, onun etik ve ahlaki değerlerden yoksun olması yönettiği halkın da bu değer ve ilkelerden yoksun kalacağı anlamina gelmektedir (Farabi, 2017b: 101-110).

Erdemli Şehir'de erdemli başkandan sonra milletlerin nasıl mutlu olacakları konusunda eğitim görmüş bir aydınlar sınıfi bulunmaktadır. Bu sınıfın görevi, halkı ikna etmek ve eğitmektir ve onlar, bu görevi yerine getirirken başkanın izlediği yolu takip etmektedir. Aydınlar sınıfının verdiği eğitim, kötü eylemleri ortadan kaldırmalıdır; zira tabii ve iradi kötülükler ortadan kaldırılmadan mutluluk elde edilemez. Eğer eğitim, bazı insanları doğru ve iyi davranışlara yönlendirmede yetersiz kalıyorsa, o zaman Erdemli Başkan gereken hallerde zorlayıcı usullere başvurmalıdır (Farabi, 2017a: 24-26).

\subsubsection{Adalet}

Farabi'ye göre devlet yönetimi; bilimdir, sanattır, bilgeliktir ve "mutluluk düşüncesi" üzerine kuruludur. İnsan mutluluğa ulaşma amacını bireysellikten çok toplumsal ortamda yani erdemli bir şehirde gerçekleştirebilir. Bu noktada devletin temel amacı; mutsuzluğu en aza indirmektir. Bunu da sevgi bağlarını güçlendirerek ve adaleti tesis ederek sağlayacaktır (Kars, 2006: 35).

Farabi, adalet ilkesine dair görüşünü "herhangi bir erdemin, insanın diğer insanlarla olan iliş̧isindeki uygulamalara" bağlı olarak açıklamakta ve "Tabii adalet" fikrine karşı çıkmaktadır (Fahri, 1992: 116-117). Bu fikre neden karşı olduğunu ise şöyle dile getirmektedir;

"Eskilere göre adalet, tabiata uygun olan ve zorla elde edilen hâkimiyettir. Adalet, her kim olursa olsun, insanın yolu üzerine dikilen varlı̆̆ın ezilmesidir. Ezilen, bu ezilme ile bedenin güvenliğini kaybeder ya da yok olur. Böylece ezen varlikta tek kalır ya da ezilen bu ezilmede şerefini kaybeder, aşağglanmış bir şekilde hayatını sürdürür veya ezen kişinin kölesi olarak ezen kişi için en yararlı olan şeyi yapmak zorunda kalır. O halde ezen kişinin ezileni 
kendisine köle yapması adalete uygun olduğu gibi, ezilen kişinin ezen kişi için en yararl olan şeyi yapması da adalete uygundur. Bütün bu durumlar, tabii adalete uygundur ve erdemli davranışlardır."

Farabi'ye göre bu, aldanılmış ve yanılmışlıktan başka bir şey değildir. Bu mantıkla adalet ilkesine uygun davranan ve onun kurallarını uygulayan kişi ise kendisinin başkasına yapmak istediği şeyin bir yandan da kendisine yapılmasından korkan, zayıf bir insandır (Farabi, 2017b: 137-138). Erdem, mutluluk gibi hedefler, adaletsiz bir ortamda bir anlam ifade etmemekle birlikte, adalet ilkesinin uygulanması ile var olacaklardır. Erdemli şehrin parçaları ve mertebeleri evrensel kozmik yapı gibi sevgi ve inanç birliğiyle bir araya gelmektedir ve adaletle sağlamlaşarak varlı̆̆ını idame ettirmektedir (Demirel, 2014: 368).

\subsubsection{Liyakat}

Farabi, etik değer ve ilkelerden olan "liyakat" ile ilgili düşüncelerini; "İnsanlar, yatkın olduklarl şeylerle, bu şeylerin en son veya en yakın yetkinliklerini almak üzere eğitilirler. Herhangi bir iş konusunda öyle yüksek yaratıllşlar vardır ki, bunlar, onların yatkın oldukları şeylerle eğitilmez ve ihmal edilirse, zamanla onların sahip olduklarl yetenekler yok olur. Bazen de söz konusu işte kötü şeylerle eğitilirlerse bayağı şeyler bulunup ortaya çıkarılmış olur" cümleleriyle belirtmektedir. Farabi'ye göre insanların sanat ve bilim türlerine yatkınlıkları yaratılışları itibariyle farklıdır. Eşit yaratılışta olanlar, yatkın oldukları şeylerde eğitilmelerindeki farklarından dolayı birbirlerinden üstündürler. Eşit bir şekilde eğitilenler de buluş güçlerindeki üstünlükten dolay1 farklıdırlar. Bir şeyi bulma gücüne sahip olan, daha az şeyleri bulma gücüne sahip olanların başkanıdır. Ayrıca rehberlik ve öğretimin iyilik ya da kötülügüne ve eğitimle kazanılmış güçlerin üstünlüklerine göre kişiler birbirlerinden üstündür. İyi kılavuzluk ve eğitim gücüne sahip olan kimse, üstün olur ve diğerlerinin de başkanı olur (Farabi, 2017a: 89-90).

\subsubsection{Liderlik}

Farabi, "liderlik" kavramına Erdemli Şehir'in bütününde yer vermiş ve liderde bulunması gereken özellikleri ayrıntılı olarak açıklamıştır. Farabi’ye göre başkan kötü ise devlette kötü; başkan iyi ve erdemli ise devlette iyidir. İyi başkan aynı zamanda, peygamber ile filozofun bütün olumlu vasıflarını üzerinde toplayan kişi olarak betimlenmektedir (Farabi, 2017a: 22). Dahası Erdemli toplumun yöneticisi, kendisinin üzerinde başka bir insanın hükmünün bulunmadığı hâkim kişidir. $\mathrm{O}$, önderdir, erdemli şehrin ilk başkanıdır, erdemli milletin hükümdarıdır, insanlığın en üst konumunda ve mutluluğun en yüksek derecesindedir. Ayrıca $O$, insanları mutluluğa ve bu mutluluğun elde edildiği eylemlere en iyi bir biçimde yöneltme gücüne sahip kişidir. Farabi'ye göre bu durumlara, ancak kişiliğinde doğuştan sahip olduğu on iki özelliğe sahip olan insan ulaşabilir. Bu özellikler şu şekildedir (Farabi, 2017b: 105-108):

a) Erdemli başkanın bütün organları tam ve eksiksiz olmalıdır. Bir eylemi gerçekleştirirken sorunsuz, kolayca yapabilmelidir.

b) Üstün bir anlama ve kendi mantı̆ğına uygun olanları yapabilme kabiliyetine sahip olmalıdır.

c) Hafızası güçlü olmalı, unutmamalı ve yaptığı her şeyi bilinçli yapmalıdır.

d) Uyanık ve çok zeki olmalıdır.

e) Düşündüklerini açık bir şekilde ifade edecek güçlü bir hitabete sahip olmalıdır.

f) Gümüş, altın ve benzeri dünyevi şeylere karşı zaafı olmamalıdır.

g) Bilgiyi, bilgi edinmeyi ve öğrenmeyi sevmelidir. Ne kadar güç durumda olursa olsun bilmek için uğraş vermelidir.

h) Doğruyu, doğruluğu ve doğru insanları sevmelidir. Yalandan nefret etmeli, yalan söyleyenleri kendinden uzaklaştırmalıdır.

i) Bütün kötü alışkanlık ve zevklerden uzak olmalıdır. 
j) Yüksek ruhlu olmalı; şerefi, ululuğu sevmeli; ruhu doğası gereği çirkin ve aşağılık şeylerin üstünde olmalıdır.

k) Yaratılışı gereği adaleti ve adil insanları sevmelidir. Baskı ve zulüm yapanlardan ise nefret etmelidir. Yönettiği kimselere ve diğer insanlara karşı insaflı olmalıdır. Güzel ve doğru gördüğü her şeyi desteklemelidir. Adil olmaya ve adaletle yönetim gerçekleştirmeye davet edildiğinde inat etmemeli ve isteksiz olmamalıdır. Aksine haksızlık ve kötülük karşısında dirençli, istekli ve kararlı olmalıdır.

1) Yapılmasını istediği şey konusunda 1srarcı, azimli olmalı, korku ve zaaf göstermeksizin cesur bir şekilde onu gerçekleştirmelidir.

Bütün bu özelliklerin bir arada olduğu bir insana rastlamanın kolay olmadığına değinen Farabi, doğal yaratılışında bu özellikleri taşıyan insana her çağda bir kere rastlanabileceğini söylemektedir. Eğer erdemli şehirde bu özelliklerin altısına sahip olan bir insan varsa, o kişinin yönetici olması gerektiği de ayrıca vurgulamaktadır (Farabi, 2017b: 108):

İlk yöneticiden daha sonra gelip ona vekâlet edecek yönetici ise doğuştan sahip olacağı on iki özellik yanında altı özelliğe daha sahip olmalıdır. Bunlar (Farabi, 2017b: 109):

a) Bir filozof olmalıdir.

b) İlk yöneticilerin erdemli şehir için koydukları kanunları, kuralları, usulleri bilmeli ve bunları korumalıdır. Bütün eylemlerinde ilk yöneticilerin izinden gitmelidir.

c) Yeni kanunlar icra etmelidir.

d) İlk yöneticilerin kendileriyle ilgili olarak herhangi bir kanun koymalarının mümkün olmadığı durumda, onların ardından herhangi bir olay karşısında doğru hüküm verebilmeli ve bu konuda akıl yürütme ve derin düşünme yetisine sahip olmalıdır.

e) İlk yöneticilerin kanunlarıla kendi çıkardığ 1 yeni kanunlar konusunda halka açılama yapmalı, onlara her konuda rehber olmalıdır.

f) Yönetim ve belirli diğer işlerin yanında savaş gibi özel konularda üzerine düşeni yapabilmek için beden sağlığı yerinde olmalıdır.

Eğer bütün şartları yerine getiren bir kişi bulunamazsa, biri sadece filozof olan ve diğeri de geriye kalan tüm şartları taşıyan iki kişi şehrin yöneticileri olmaktadır. Felsefe ve filozof yönetimin bir parçası olmaktan çıktığı vakit Erdemli Şehir hükümdarsız kalmış olur, şehir halkı da helak olma tehlikesi ile karşı karşıya kalır (Farabi, 2017b: 109). Hükümdar yanında Erdemli Şehrin halkı da bilgiye, doğruya, adalete, mükemmelliğe ve tüm erdemli vasıflara uygun hareket etmelidir. Herhangi bir ihmalkârlık, eksiklik, kötülük bu insanlarda vücut bulmamalıdır. Bu halk, amaç olarak bir ve aynı mutluluğa sahip olan, aynı amaç peşinde koşan insanlardan meydana gelmelidir (Farabi, 2017b: 127-128).

\subsubsection{Bilgi}

Farabi, "bilgili olmak" hususuna da sıkça değinmektedir. Zira Erdemli Şehir'in yöneticisi, bilgili ve bilge kişi olmak zorundadır. Ona göre, mutluluğu amaç edinen insanların çoğu, onu göz önüne getirerek değil, ancak hayal ederek amaç edinir. İnsanların çoğu da benimsenen, uyulan ve yüceltilen ilkeleri, göz önünde canlandırılmış şekilleriyle değil, ancak hayal edilmiş şekilleriyle kabul ederler. Mutluluğu göz önünde canlandırılmış şekliyle amaç edinen ve ilkeleri bu şekliyle kabul edenler "bilge kişiler"dir. Bu şeyleri nefislerinde hayal edilmiş şekilleriyle kabul eden ve amaç edinenler ise inanan (mümin) kişilerdir (Farabi, 2017a: 100-101).

Farabi'nin yaşadığı çağ adına bilgiye ve bilime yüklediği anlam ve epistemolojik olarak bilim veya bilgi tasnifinde ele aldığı noktalarla birlikte "bilmeye" verdiği önem üst düzeydedir. Bu bağlamda bilgiyi insanlar arasında "üstünlük" vasfi olarak nitelendiren anlayışı, İslam düşüncesinin gelişimine ve yaşadığ niteliktedir (Çaylak ve Çelik, 2019: 398). 
Eserin içeriğinde, erdemli bir başkandan gelen her şeyin iyi, faziletli ve halkın mutluluğu ile doğrudan alakalı olduğunu Farabi 1srarla tekrarlamaktadır. O, tıpkı görüşlerinde benzerlik olan Aristoteles gibi, kötü huy ve davranışlara sahip olan kişilerin cezalandırılmaları gerektiğini de vurgulamaktadır. Kötü davranışlarından dolayı ceza alan bir kimsenin ıslah olmaması durumunda ise onun tamamen toplumdan uzaklaştırılmasını tavsiye etmektedir. Nitekim erdemli başkanın, kötüye karşı savaş açma yetkisi vardır ve açılan bu savaş, mutluluğa ulaşmak için faziletli bir savaştır. Aynı zamanda bu savaş, doğru yolda olmayanların kurtuluşu ve mutluluğu için bir çözümdür (Farabi, 2017a: 25-26).

Farabi'nin değerler teorisi, etik/ahlak anlayışı ve siyaset kuramı onun tasarladığı ElMedinetü'l Fazıla adlı eserinde yani Erdemli Şehir'de karşımıza çıkmaktadır. O, bu eserinde mutluluk, iyilik, kötülük, erdem, sevgi, onur, adalet, liyakat gibi değer ve ilkelerden bahsederken, karşıt durumlarının yaşandığ 1 şehirleri etik/ahlaki değer ve ilkelere sahip olma açısından Fasık, Cahil, Sapık olarak sınıflandırmıştır. Erdemli ve mükemmel şehre zıt olan şehirler; Cahil, Bozuk (fasık) ve doğru yolu bulamamış yanlışlık içinde olan Sapık (dâlla) şehir'dir. Bu şehirlerin hepsinin halkı da erdemli şehirde yaşayan erdemli halka zıttır (Farabi, 2017b: 111):

a) Cahil (bilgisiz) şehir: $\mathrm{Bu}$ şehrin insanları bilgisizdir ve mutluluktan uzaktır. Mutluluk için eylemde bulunmayan bu topluluk; servet ve zenginliği, zorunlu şeyleri veya onların yerine geçen altın ve gümüş parayı bolca elde etmek, sırf zenginlik tutkusundan ve cimrilikten dolayı ihtiyaçlarının ötesinde birikim sağlamak ister ve bu amaçla işbirliği yaparlar (Farabi, 2017a: 103-121).

b) Fasık (bile bile kötülük işleyen) şehir: Bu şehrin insanları, mutluğun ne olduğunu bilirler, onu hayal ederler. Ancak davranışlarında bilgisiz(cahil) şehrin insanları gibi davranırlar. Yani temel amaçları mutluluğa ulaşmak değil; mevki, şeref, egemenlik gibi güçlere erişmektir (Farabi, 2017a: 121-122).

c) Sapık (dâlla) şehir: Bu şehrin insanları kendileri ilkeler belirleyip, gerçek mutluluğun taklidine ulaşmışlardır. Onlara sunulan ve onlar için ortaya konan mutluluk, gerçek mutluluktan ziyade mutluluğun bir taklididir. Bu nedenle bu şehirde yaşayanlar, sahte mutlulukla bozuk bir şehir hayatı yaşamaktadır (Farabi, 2017a: 122).

Diğer yandan bu kötü yönetim türlerinin sayısı ve çeşidi artabilir. Ancak hepsinin "erdemsiz" başlığı altında toplanması bilgi açısındandır. Çünkü bilgi, genel kanunları kapsar ve tespit eder. Bu yönetimlerin her birinin eylemleri, bilgiden ve elde edilen yönetim sanatından değil, ancak başkanlarının düşünce ve kendi isteklerinden meydana gelmektedir. Her ne kadar bunlar arasında biri bir diğerinden derece bakımından iyi olsa da hepsi kötü siyaset, şehir, ulus, uluslar birliği ve başkanlık adını almaktadır (Kars, 2006: 32).

\section{Sonuç ve Değerlendirme}

Günümüzde etik, bireylerin tavır ve davranışlarında doğruyu bulmalarında onlara yardımcı olacak bir rehber olma yanında kamu yönetiminde kamusal reformların bir parçası ve devletin olmazsa olmaz bir unsuru olarak görülmektedir. Atfedilen bu rolüne ve kavramsal olarak çok eski bir geçmişe sahip olmasına rağmen kamu yönetimi sistemlerinde dikkate alınması ve uygulanabilir kılınması içinse 1980'li yılları beklemek gerekmiştir. Günümüz modern etik anlayışı, çeşitli ideoloji, yaklaşım ve görüşlerin bir ifadesi olarak kamu yönetiminde insan haklarına saygıll, eşit, adil, demokrasi temelli, vatandaş odaklı bir kamu yönetimi yapısı meydana getirme düşüncesi ile hareket etmektedir. Özellikle kamu yönetimi için geçerli etik kodlar, ilkeler belirlenerek kamu yönetimini şeffaf ve hesap verebilir bir yapıya kavuşturmak, bu sayede daha etkin ve etkili bir yönetim gerçekleştirmek amaçlanmaktadır. Bu ilkelere uygun davranılmasının aynı zamanda yönetimdeki etik dışı faaliyetleri azaltacağı ve hatta önüne geçeceği ve böylece hizmet alan halkın devlete, kurumlara ve kamu görevlilerine güven duydukları bir ortamın sağlanacağı düşüncesi hâkim kılınmaya çalışılmaktadır. 
Öte yandan çalışmada üzerinde durulan Türk yönetim kültürünün gelişen ama aynı zamanda süreklilik arzeden bir yapıya sahip olması konusunda çeşitli dinamikler göze çarpmakta ancak temel amacın ideal bir devlet düzenine sahip olmak olduğu düşünülmektedir. Bu çerçevede ideal bir devlet düzenine, yönetimine sahip olmak için gerekli şartların neler olduğunu belirtmek üzere bazı düşünür ve devlet adamlarınca siyasetnamelerin kaleme alındığı görülmektedir. $\mathrm{Bu}$ siyasetnameler ise devlet yöneticileri başta olmak üzere devlet hizmetinde bulunan diğer görevlileri doğruluğa ve dürüstlüğe yönlendirmek; halka hizmet düşüncesinin önemini aşılamak; var olan durumdaki olumsuz davranışların zararlarından bahsetmek; adil, eşit, etik davranışlar sergileyen bir yönetim gerçekleştirmeyi öğütlemek amacıyla yazılmıştır. Ahlaktan siyasete, ekonomiden diplomasiye pek çok alanda devlet ile halk arasındaki ilişkilere değinen bu siyasetnameler, dini esaslar ve ahlaki değerler yanında yönetim ilkeleri olarak zikredilen ve içerisinde etik değer ve ilkeleri barındıran kavramlara da yer vererek yazarın düşüncelerini yansıtmıştır.

$\mathrm{Bu}$ çalışmada, Türk yönetim kültüründe önemli addedilen siyasetnamelerden biri olan Farabi'nin El Medinetü'l Fazıla (Erdemli Şehir) adlı eseri Farabi'nin ahlak anlayışında yer alan değerler açısından incelenmeye çalışılmıştır ve bu çalışmada 2000'li yıllarda belirlenen etik değer ve ilkelerden sayıca çok az bir kısmıyla karşılaşılmıştır. Günümüzün etik ilke ve değerleri hesap verebilirlik, şeffaflık, sorumluluk, adalet, hukukilik, dürüstlük ve tarafsızlık, eşitlik, açıklık, liderlik, liyakat ve profesyonellik, nesnellik, sadakat, nezaket ve saygı, saygınlık ve güven, kamu hizmet bilinci, halka hizmet bilinci, hizmet standartlarına uyma, amaç ve misyona bağll1ık, yetkili makamlara bildirim, çıkar çatışmasından kaçınma, görev ve yetkilerin menfaat sağlamak amacıyla kötüye kullanılmaması, hediye alma ve menfaat sağlama yasağı, savurganlıktan kaçınma, mal bildiriminde bulunma gibi uzun bir liste halinde sıralanırken Farabi'nin etik anlayışının eski yunan düşünürlerinin ve İslamiyet'in etkisi ile oluştuğu ve öz itibariyle mutluluk temelinde kurgulandığı görülmektedir. Farabi’nin öğretisinde tek amaç mutluluk değerine ulaşmaktır ve Erdemli Şehrin yöneticisi ve onun yönetimi altında bulunanlar da tek gaye olarak mutluluğa ulaşmay hedeflemektedir. Mutluluk kavramı her ne kadar günümüz kamu yönetimi sistemlerinde etik bir değer olarak görülmese de kamu görevlilerinin görevlerini yerine getirirken halka hizmet bilinci ile hareket ettikleri takdirde hem kendilerinin mutlu olacağını hem de hizmet bekleyen vatandaşı memnun edecekleri noktasında var olduğu söylenebilir.

Farabi tarafından tasarlanan ve ideal devlet yönetimi ve yöneticisinin nasıl olacağına dair bilgiler veren El-Medinet'ül Fazıla (Erdemli Şehir)'da, bütün erdemlere sahip olan bir şehir görüntüsü çizilmiş ve etik kavramının açıklanmasında ilk kullanılacak kavramlardan olan iyi ve kötü derinlemesine açıklanmıştır. Ayrıca 2000'li yıllardan itibaren söz konusu olan etik değer ve ilkelerden "adalet", "liyakat", "liderlik", "bilgili olmak" hususlarına El- Medinet'ül Fazıla (Erdemli Şehir)'nın genelinde yer verilmiştir. Günümüz etik değerleriyle bir karşılaştırma yapıldığında da sadece bu dört ilke eserde göze çarpmıştır. Tabi ki şunu da belirtmek gerekir ki Farabi'nin benimsemiş olduğu etik anlayış ile günümüz modern etik anlayışı arasında belli farklar vardır ve bu farklılığın temelinde Farabi'nin etik anlayışını din- devlet- ahlak zemininde olgunlaştırması bulunmaktadır.

$\mathrm{Bu}$ gelişmelerin olumsuz ve üzüntü veren tarafi ise Türk yönetim kültürünün köklü ve sürekli bir yapıya sahip olmasına, yönetim ilkelerinin yüzyıllar öncesinde belirlenmesine ve bahsi geçen siyasetnamede yönetim ilkeleri adı altında bazı etik değer ve ilkeler alınmasına rağmen günümüz yönetim sürecinde etik olgusunun yerleştirilmeye çalışılmasıdır. Nitekim bu siyasetname özelinde 8. yüzyıldan itibaren kaleme alınmaya başlanan ve Türk yönetim tarihinin hemen her döneminde yazılmış siyasetnamelerin temel gayesi etik değer ve ilkelerden oluşan yönetim ilkelerinin devlet yönetiminde benimsenmesi ve yolsuzlukla mücadele konusu ile ilgili olmuştur. Ancak günümüzle karşılaştırıldığında gerek bireysel açıdan gerekse kamu görevlileri açısından bu konuda kayda değer bir gelişmenin yaşanmadığ 1 görülmektedir. 


\section{Kaynakça}

Acar, M., Guo, C. ve Yang, K. (2008). "Accountability When Hierarchical Authority Is Absent", The American Review of Public Administration. Vol.38. Number 1. 3-23. https://doi.org/10.1177/0275074007299481

Adalığlu, H. H. (2009). "Siyasetname”. TDVIA. Cilt 37. 304-306.

Alodal1, M. F. B. ve Usta, S. (2017). "Türk Yönetim Geleneğinde Hesap Verebilirlik Mekanizmaları: Divan-1 Mezalim ve Kamu Denetçiliği Kurumu”. Strategic Public Management Journal. Cilt 3. Say1 6.168-184. https://doi.org/10.25069/spmj.341437

Akarsu, B. (2010). Felsefe Terimleri Sözlüğü. İnk1lap Kitapevi. 11.bask1. İstanbul.

Arap, İ. ve Yılmaz, L. (2006). "Yeni Kamu Yönetimi Anlayışının "Yeni” Kurumu; Kamu Görevlileri Etik Kurulu". Amme İdaresi Dergisi. 39 (2), 51-69.

Atiyas, İ. ve Sayın, Ş. (2000). "Devletin Mali ve Performans Saydamlığı”. Kamu Maliyesinde Saydamlık. TESEV. İstanbul. 27-43.

Ayaz, A. (2008). "Farabi'de Siyaset Kaynakları ve Etkileri”. Yayımlanmamış Doktora Tezi, Marmara Üniversitesi SBE. İstanbul.

Aydın, İ. (2016). Yönetsel, Örgütsel ve Mesleki Etik. Pegem Akademi Yayıncılık. Ankara.

Baykara, T. (2011). Türk Kültürü, IQ Sanat Yayınc1lı. 4. Bask1. İstanbul.

Belen, M. (2015). “ Siyasetnameler ve Bir Siyasetname Örneği: Adab-1 Saltanat”. JASSS (The Journal of Academic Social Science Studies). Say1 34. 275-283. "https://doi.org/10.9761/jasss2858"

Bertók, J. (2005). "The Role of Transparency in Preventing Corruption in Public Procurement: Issues for Consideration". Fighting Corruption and Promoting Integrity in Public Procurement, OECD Publishing. 85- 93. https://doi.org/10.1787/9789264014008-en

Beth, E. (2005). "Main Findings of the Forum Workshop on 'Improving Transparency in Public Procurement". Fighting Corruption and Promoting Integrity in Public Procurement, OECD Publishing. 45-51. https://doi.org/10.1787/9789264014008-en

Çiçek, K. (1997). "Siyasetname Kültürümüze Göre Siyasetteki Yozlaşma ve İdeal Siyaset”. Yeni Türkiye Dergisi. 3(13), 1384-1388.

Çaylak, A. ve Çelik, F. (2019). "Farabi (870-950)”. İslam Siyasi Düşünceler Tarihi. ed. Adem Çaylak. Savaş Yayınevi. 2.Baskı.

Çeçen, A. (1985). “Kültür Yönetimi”. Amme İdaresi Dergisi. 18(2), 113-140.

Çubukçu, İ. A. (1989). Türk- İslam Düşünürleri. Türk Tarih Kurumu Basımevi. XXIV.dizi. Sayı 8. Ankara.

Demirel, D. (2014). “Farabi'nin İdeal Devleti: Erdemli Şehir”. Ömer Halisdemir Üniversitesi İktisadi ve Idari Bilimler Fakültesi Dergisi. 7(1). 358-369. https://doi.org/10.25287/ohuiibf.339753

Erdinç, A. ve Gül, H. (2009). "Saydamlık ve Hesap Verebilirliliğin Kamu Yönetiminde Etik Anlayışındaki Yeri”. Kamu Etiği Sempozyum Bildirileri 2. TODAİE. Ankara. 953-970.

Eryılmaz, B. (2013). Kamu Yönetimi. Umuttepe Yayınları. 6.Baskı.

Evkuran, M. (2009). "Siyasal Kültür, Kamu Etiği ve Yolsuzluk Sorunu”. Kamu Etiği Sempozyum Bildirileri 2. TODAIE. 639-659. 
Fahri, M. (1992). İslam Felsefesi Tarihi. çev., Kasım Turhan. İklim Yayınları. 2. Bask1. İstanbul.

Farabi (2017a). Es- Siyasetü'l- Medeniyye veya Mebadi'ül- Mevcudat. çev., Mehmet Aydın. Abdülkadir Şener, M. Rami Ayas. Büyüyenay Yayınları. 2. Baskı.

Farabi (2017b). İdeal Devlet. çev., Ahmet Arslan. Türkiye İş Bankası Kültür Yayınları. İstanbul.

Fromm, E. (1994). Erdem ve Mutluluk. çev., Ayda Yörükan. Türkiye İş Bankası Kültür Yayınları.

Gözler, K. ve Kaplan, G. (2014). İdare Hukukuna Giriş. Ekin Basın Yayın Dağıtım. 19. Baskı.

Gül, S. K. (2008). “ Kamu Yönetiminde ve Güvenlik Hizmetlerinde Hesap Verebilirlik”. Polis Bilimleri Dergisi. 10(4), 1-94.

Halachmi, A. ve Greiling, D. (2013). "Transparency, E- Government and Accountability". Public Performance \& Management Review. Vol. 36. No. 4. 562- 584. https://doi.org/10.2753/pmr1530-9576360404

Halaçoğlu, Y. (2014). XIV-XVII. Yüzyıllarda Osmanlılarda Devlet Teşkilatı ve Sosyal Yapı. Türk Tarih Kurumu Yayınları. Ankara.

Kafesoğlu, İ. (1995). Türk Milli Kültürü. Ötüken Neşriyat Yayınları.

Karakaş, M. (2005). “ Kamu Mali Yönetiminde Yeniden Yapılanma Aracı Olarak Hesap Verme Sorumluluğu ve Saydamlı". Süleyman Demirel Üniversitesi İktisadi ve İdari Bilimler Fakültesi Dergisi. 10(2), 291-305.

Kars, Z. (2006). "Farabi'de İnsan-Devlet İlişkisi". Atatürk Üniversitesi Sosyal Bilimler Enstitüsü Dergisi. 7(1). 21-38.

Kesim, E. (2005). "Bir Etik Davranış İlkesi Olarak Hesap Verebilirlik”. 2. Siyasette ve Yönetimde Etik Sempozyuтu. 18-19 Kasım. Sakarya. 269-281.

Kılıç Özkaynar, G. (2017). “ Tarihte Öne Çıkan Türk Lider Örnekleri Üzerine Bir İnceleme”. Ekonomi, İşletme ve Yönetim Dergisi -Karabük Üniversitesi. 1(1), 10-31.

Koçberber, S. (2008). “ Dünya'da ve Türkiye'de Denetim Etiği”. Saylştay Dergisi. Say1 68. 65-89.

Köprü, B. (2007). “Türk Kamu Yönetiminde Etik Değerlerden Sapma ve Yönetsel Yozlaşma”. Yayımlanmamış Yüksek Lisans Tezi. Gazi Üniversitesi SBE. Ankara.

Levend, A. S. (1962). "Siyaset-Nameler". Türk Dili Araştırmaları Yıllı̆̆ı. Belleten. Cilt 10, 168183.

Mandaloğlu, M. (2013). "İslamiyetten Önceki Türklerde Aile Hukuku”. Türkiyat Araştırmaları Dergisi. Say1 33. 133-159.

Memiş, E. (2015). Türk Kültür Tarihi (Türk Kültüründen Bazı Kesitler). Ekin Yayınları. 5.bask1.

Mulgan, R. (2000). “Accountability': An Ever- Expanding Concept?". Public Administration. Vol.78. No.3. 555-573. https://doi.org/10.1111/1467-9299.00218

Önder, Ö. ( 2018). "Siyasetnameleri Yeniden Okumak". Sungur Türk Fikir Mecmuası. Sayı 3. Ocak- Şubat. 12-16.

Öztürk, N. K. (2005). "İtaatkâr Kamu Görevlilerinin Etik Sorunları”. 2. Siyasette ve Yönetimde Etik Sетроzуити. 18- 19 Kasım. Sakarya. 327-345.

Pamir, A. (2009). "Orta-Asya Türk Hukukunda "Töre" Kavramı". Ankara Üniversitesi Hukuk Fakültesi Dergisi. Cilt 58. Say1 2. 359-375. https://doi.org/10.1501/hukfak_0000001574

Saylam, G. (2007). "Kamu Yönetiminde Etik Çalışmalar ve Türkiye'deki Son Gelişmeler”. Gazi Üniversitesi SBE. Yayımlanmamış Yüksek Lisans Tezi. Ankara. 
Saylı, H. ve Kızıldağ, D. (2007). "Yönetsel Etik ve Yönetsel Etiğin Oluşmasında İnsan Kaynakları Yönetiminin Rolünü Belirlemeye Yönelik Bir Analiz”. Afyon Kocatepe Üniversitesi Sosyal Bilimler Dergisi. 9(1), 233-251.

Sı̆̆rı, Ü., Ercil, Y. ve Başar, U. (2015). Geçmişten Günümüze Türk Yönetim Uygulamaları. Beta Yayınc1lı. İstanbul.

Stroll, A.A., Long, A.A., Bourke, V.J. ve Campbell, R.(2017). Etik Kuramları. der. ve çev., Mehmet Türkeri. Lotus Yayınları. 4. Baskı.

Şen, M. L. (2012). Kamu Görevlileri Etik Kurulu Rehberi. T.C. Başbakanlık Kamu Görevlileri Etik Kurulu. Ankara.

Taneri, A. (1981). Türk Devlet Geleneği (Dün-Bugün). Töre Devlet Yayınevi.

Tdk Güncel Türkçe Sözlük. “Siyasetmame”. sözlük.gov.tr (Erişim Tarihi:15.12.2019)

Terzi, M. A. (2015). Türk Devlet Geleneğinde Bürokrasi. Bilge Kültür Sanat Yayınc1lı. İstanbul.

Uluğ, F. (2009). "Yönetim ve Etik”. Kamu Etiği Sempozyum Bildirileri 1. TODAİE. 25-26 Mayıs. 3-15.

Usta, A. (2010). "Kamu Görevlisinin Etik Amaç ve Ahlaki Yükümlülüğüne Yönelik Bir Değerlendirme”. Türk İdare Dergisi. Sayı 468. 159-181.

Yatkın, A. (2008). "Etik Düşünce ve Davranışın Yerel Yönetimlerde Hizmet Verimliliğinin Arttırılmasında Rolü ve Önemi (Elazı̆ Belediyesi Örnek Alan Araştırması)". Fırat Üniversitesi Sosyal Bilimler Dergisi. Cilt 18. Say1 1. Elazığ. 211-231.

Yatkın, A. (2015). Kamuda Etik Yönetimi. Nobel Akademi Yayınları. Ankara.

Y1lmaz, C. (2009). "Siyasetname (Osmanlı Dönemi)". TDVIA. Cilt 37. 306-308.

Yüksel, C. (2007). “Kamu Yönetiminde Etik Davranış Kuralları”. Ed., Bilal Eryılmaz, Musa Eken, Mustafa Lütfi Şen. Kamu Yönetimi Yazıları. Nobel Yayınları. 582-606.

Yüksel, C. (2010). Devlette Etik. Boğaziçi Üniversitesi Yayınevi. İstanbul.

1982 Anayasas1 madde 10, Resmi Gazete: 09. 11. 1982, Say1: 17863

Kamu Görevlileri Etik Davranış İlkeleri ve Başvuru Usul ve Esasları Hakkında Yönetmelik, Resmi Gazete: 13. 04. 2005, Say1: 25785.

657 Devlet Memurları Kanunu, madde 3, Resmi Gazete: 10. 07. 1965, Sayı: 12056 